\title{
NATIONAL AND REGIONAL SPECIFICATIONS \\ OF NONVERBAL COMMUNICATION MEANS
}

Prokopovych Lidiia, Popovych Nadiia, Kurylo Oleksandra

\section{НАЦІОНАЛЬНА ТА РЕГІОНАЛЬНА СПЕЦИФІКА НЕВЕРБАЛЬНИХ ЗАСОБІВ СПІЛКУВАННЯ}

Прокопович Л. С., Попович Н. Ф., Курило О. Й.

The article deals with the national and regional specificity of non-verbal means of communication. The definitions of notions «culture of language», "verbal communication», "nonverbal communication» are given. The relevance of topic of the study is conditioned by the fact that cultural, psychological, national characteristics of the people can not affect their business culture, and can not affect the culture's communication and interaction. The differences of cultures can be quite significant and relate to language, etiquette rules, stereotypes of behavior, usage of certain means of communication. The purpose of the article is to characterize the national and regional specificity of non-verbal communication in a multicultural world. The basic methodological principle of the research is an interpretative methodology that helped to define the functions of language in the society, and specific methods and techniques: descriptive, comparative, comparative.

The study found out that in addition to language, there are other means of communication. People exchange information through gestures, facial expressions, looks, postures, body movements, which are called non-verbal (nonverbal) means of communication.

The main attention is given to some kinetic non-verbal means that are considered in the context of national traditions.

Engaging with foreign partners is always a clash of different national cultures. Just because of the lack of awareness in this issue some contacts with representatives of different countries result in misunderstandings and sometimes conflicts. At the stage of implementation of contacts, certain national peculiarities of individual peoples are revealed. These features should be taken into account preparing for any negotiations with foreigners and their actions should be adjusted accordingly. We see the prospect of further research in the study and analysis of national and regional specificities of verbal communication.

Key words: sociopsycholinguistics, ethnopsycholinguistics, language culture, multicultural world, mentality, verbal communication, non-verbal communication.

У статті розглянута національна та регіональна специффіка невербальних засобів спілкування. Подано визначення понять «культура мови», «вербальне спілкування», «невербальне спілкування». Актуальність теми дослідження обумовлена тим, щуо культурні, психологічні, національні особливості народу не можуть не позначатися на його діловій культурі, не впливати на культуру спілкування та взаємодії. Відмінності культур можуть бути досить істотними і стосуватися мови, правил етикету, стереотипів поведінки, використання певних засобів спілкування. Метою статті є схарактеризувати національну та регіональну специфіку невербальних засобів спілкування в полікультурному світі. Основний методологічний принщип дослідження - інтепретативна методологія, яка допомогла визначити функиії мови в сочіумі, та конкретні методи і прийоми: описовий, зіставний, порівняльний.

У результаті дослідження визначено, щуо крім мови, мовлення існують інші засоби комунікації. Люди обмінюються інформацією за допомогою жестів, міміки, погляду, пози, рухів тіла, які називають невербальними (несловесними) засобами спілкування.

Головну увагу приділено окремим кінетичним невербальними засобам та розглянуто їх в контексті національних традииій. 
Взаємодія з іноземними партнерами - це завжди зіткнення різних національних культур. Саме через неусвідомлення цьього при контактах представників різних краӥн відбуваються непорозуміння, а іноді ц̌ конфлікти. На стадї реалізації контактів виявляються певні національні особливості, притаманні окремим народам. Ці особливості слід враховувати, готуючись до будь-яких переговорів з іноземиями, і відповідним чином коригувати свої дії. Перспективу подальшого дослідження вбачаємо у вивченні та аналізі національної та регіональної специфіки вербальних засобів спілкування.

Ключові слова: соціопсихолінгвістика, етнопсихолінгвістика, культура мови, полікультурний світ, вербальне спілкування, невербальне спілкування.

In the age of globalization, due to the widespread availability of certain goods and ideas, local cultures are changing and the boundaries between them become more transparent. Due to the development of vehicles, economic ties and communication, the process of integrating individual ethnic cultures into a single world culture, that is, the process of globalization of culture, takes place. At the same time, culture is seen as a set of values and behaviors adopted in a particular country or group of countries and mastered by the majority.

In intercultural communication, it is manifested in the expansion of cultural contacts, the borrowing of cultural values and the migration of people from one culture to another. In view of this, the United Nations, in particular, proclaimed 2001 the Year of Dialogue between Cultures.

Language culture is another commonly accepted language of etiquette: the usual formulas of greetings, farewells, wishes, invitations. They vary depending on the communicative situation, the social status, the educational age of those who communicate.

Until recently (50s-60s of the twentieth century) sociolinguistics and ethnopsycholinguistics were not involved in the sphere of language culture, which was considered as recommendations for correctness or incorrectness, normativity or normality of statements.

Language culture begins with the self-awareness of the linguistic personality. The sociolinguistic and psycholinguistic aspects of language culture become increasingly important because of the need to foster a culture of international relations. Attentive, caring attitude to the language of each people, education of mutual respect presupposes the expansion of the so-called background, linguistic-linguistic information, which is sure to be included in the language education and therefore the culture of the language.

The identity of each nation, along with traditions, values, culture, is manifested primarily in linguistic stereotypes of behavior. They concentrate on features of national character, national temper that have been formed for centuries.

The stereotypical nature of people's linguistic behavior, which extends to people's linguistic behavior, should not, however, be perceived as a hindrance to the register of a national-linguistic «code of conduct» (though it is slowly, but changing), or as a leveling of the individual when choosing the most appropriate etiquette. Stereotyping is more about the choice of expressions of linguistic etiquette common to all in a particular historical context. Before such forms become stereotypical, they must be inserted into the cells of human memory and must be attained so that they become a kind of algorithm [1, p. 30].

Each speaker does not create a new formula each time, but can use one of the possible for mutual understanding in a particular communicative situation: the addressee's factor (his age and gender), the communicative conditions (place, time, duration of communication), the nature of the relations between the interlocutors. The knowledge of the features of the whole spectrum of accompanying means (gestures, facial expressions) also weighs here.

But even a combination of all said is not enough if the speaker does not take into account the national specificities of linguistic etiquette. For despite the many common features, the etiquette of each people is peculiar.

Analysis $f$ this problem studies. In recent years, the problem of language culture and communication culture has been the subject of interest of many scholars. This is in particular the 
research of V. Rusanivskyy [2; 3], S. Yermolenko [4; 5], N. Solohub [5], L. Matsko [6], O. Ponomariv [7]. The problem of non-verbal means of communication and the peculiarities of national styles of communicative non-verbal behavior is devoted to the scientific intelligence of I. Zyazyun, O. Lomakin, V. Nesterov, I. Pidlasyy.

In view of the above, the purpose of the article is to characterize the national and regional specificity of non-verbal means of communication in the multicultural world. The basic methodological principle is an interpretative methodology that helps to define the functions of language in society and specific methods and techniques: descriptive, comparative, comparative.

Language culture is invisible, but strongly intertwined with the national-cultural specificity of language behavior. Here is an interesting example from the practice of communication of Japanese, described in the collection of problems of ethnopsycholinguistics [8, p. 91-97]. In particular, the situation is analyzed, in which the one who listens to and the speaker speaks differently: "Today is very cold», the interlocutor says and hears in response: "Yes, indeed. Although they say spring is coming, the cold is receding». In fact, the listener was standing on the sunny side of the street, and he was not cold, but he imagined himself in the place of the interlocutor. According to the author, europeans have another model of linguistic behavior. The listener would say: «What are you, but it's very warm today!». Familiarity with the cultural traditions of national linguistic behavior enables one to comprehend the problems of the culture of language in ethno-linguistic terms, to view it broadly, not only as outward signs of etiquette, but as an insight into the depths of genuine culture based on dignity and mutual dignity.

Both verbal (non-verbal) and non-verbal (nonverbal) means of communication, which interact closely, play an important role in the communication process.

Verbal (verbalis, from verbum - word) communication is a process of information exchange through a language that occurs in a certain communicative situation, requires active mental activity and is based on a certain set of established rules.

But in addition to language, there are other means of communication. People exchange information through gestures, facial expressions, glances, postures, body movements, which are called non-verbal (nonverbal) means of communication.

Let us dwell more on the individual kinetic non-verbal means that are essentially the most important in society and consider them in the context of national traditions.

In particular, let's focus on posture, look, smile, facial expressions and gestures. Informative communicative value is out of the question, because it represents not only the state of mind of a person, but his / her intentions, his / her willingness to work. The normative / nonnormative position depends on national traditions. «If in Japan, social and cultural values are submissive, and it is not customary to sit or cross, then in the US, in certain communicative situations, it is not condemnable to put your feet on the table in front of an interlocutor. In Ukraine, it is considered a sign of lack of education to talk to a woman, an elderly person, a person of higher social status, holding hands in his pockets, and in France in such a pose it is possible to communicate even with the queen» emphasizes - Ya. Radevych-Vynnytskyy [9].

The view is differently interpreted in different ethnic communities. The Chinese, when they did not know the Europeans too well, wondered why white people were always furious: they always had big eyes. In China, Japan, and other Southeast Asian countries, interlocutors tend to avoid looking directly. In Japanese, «the eyes speak the same extent as the tongue». Therefore, in the subway, all passengers pretend to be asleep or read, so as not to meet someone's gaze: looking into their eyes is interpreted as we peeking into the fire from the key in the door lock. In France, Italy, Latin America, on the contrary, they often «stick out». According to S. Shevchuk, business, secular and intimate views are distinguished depending on the localized orientation to the interlocutor. The view directed to a triangle, the apex of which is a point in the middle of the forehead and the base is the line between the eyes, is businesslike. If the gaze is fixed below the eye line - it is a social gaze. An intimate look is directed to the triangle between the eyes and the breast [10, p. 160].

An extremely important non-verbal sign of etiquette is smile. In American society the 
motto "Keep smiling!" has been widespread for more than several decades. The Americans did not immediately come to this slogan. About 100 years ago, their educator and philosopher, Oriston Marden, persuaded his compatriots to go on a smile. He said: "Anxiety and worry can be read on every American face, they testify to our very civilization... Anxiety and discontent have become chronic phenomena and put a distinctive brand on our age and on our land. We do not yet know that such noble and sincere cheerfulness is a sign for the time being of people who are strong in spirit and certain in their power» [11]. The current smile of Americans, as their efficiency, enterprise, honesty, optimism, is not least explained by the influence of the popular book by O. Marden, «Will and Success» $[11]$.

Facial expressions and gestures are idio-ethnic signs. The French have a moving facial expression, the Fine face reacts are much more restrained, among the Japanese even and now a common face is a mask. Ukrainians are winking to make a communicative partner to pay attention to someone or something, to hint at something; the English (men) accompany this «facial gesture» with greetings.

Each nation has its own national culture, its originality and originality are manifested in the spiritual (language, literature, music, painting, religion) as well as in the material (especially economic, economic, production, etc.) spheres of life and activity. The cultural, psychological, national characteristics of people affect their business culture, they affect the culture of communication and interaction. The differences of cultures can be quite significant and relate to language, etiquette rules, stereotypes of behavior, use of certain means of communication. Engaging with foreign partners is always a clash of different national cultures. It is because of the lack of awareness of this that contacts with representatives of different countries result in misunderstandings and sometimes conflicts. At the stage of implementation of contacts, certain national peculiarities of individual peoples are revealed. These features should be taken into account when preparing for any negotiations with foreigners and their actions adjusted accordingly.

As you know, mentality is a set of stable, widespread in one or another social community, a group of ideas that reflects a special vision of the social reality of people who belong to it. Combining rational and subconscious, sensual and logical, value and other beliefs, mentality reflects the way, character, method of social and group thinking. The concept of «mentality» was formed in the early XX century in line with the Western European cultural tradition and was originally used as one of the characteristics of the rational foundations of the spiritual life of society. This concept testified to the difference between the nature and sources of thinking that existed in society. Depending on the existing mentality, the social community - the class, the people, the nation and others - have a certain susceptibility to this or that type of ideology, cultural norms, etc.

We see the prospect of further research in the study and analysis of national and regional specificities of verbal communication.

\section{References}

1. Bohdan, S. K. (1998). Movnyy etyket ukrayintsiv: tradytsiyi i suchasnist [Linguistic Etiquette of Ukrainians: Traditions and Modernity]. - Kyiv, $475 \mathrm{p}$.

2. Rusanivskyy, V. M., Yermolenko, S. YA. (1978). Zhyttya slova [Life of the word]. - Kyiv, $189 \mathrm{p}$.

3. Rusanivskyy, V. M. (1993). Yedynyy movno-obraznyy prostir ukrayinskoyi mentalnosti [The only linguistic-shaped space of the Ukrainian mentality]. Linguistics. - № 6. - pp. 3-12.

4. Yermolenko, S. YA., Dzyubyshyna-Melnyk, N. YA., Lenets, K. V. (1990). Kultura ukrayinskoyi movy: Dovidnyk [The Culture of the Ukrainian Language: A Handbook]. Kyiv, 302 p.

5. Dovidnyk z kultury movy [Handbook of Language Culture] (2005) / S. YA. Yermolenko, S. P. Bybyk, N. M. Solohub and others. - Kyiv, 399 p.

6. Matsko, L. I. et al. (2003). Stylistyka ukrayinskoyi movy [Stylistics of the Ukrainian language] / L. I. Matsko, O. M. Sydorenko, O. M. Matsko.- Kyiv, 462 p. 
7. Ponomariv, O. (2001). Kultura slova: Movnostylistychni porady [Culture of the word: Linguistic tips]. - Kyiv, 240 p.

8. Etnopsikholingvistika [Ethnopsycholinguistics] (1988). - M., pp. 91-97.

9. Radevych-Vynnytskyy, YA. (2006). Etyket i kultura spilkuvannya [Etiquette and culture of communication]. - Kyiv, 291 p.

10. Shevchuk, S. V., Klymenko, I. V. (2011). Ukrayinska mova za profesiynym spryamuvannyam [The Ukrainian language by professional direction]. - Kyiv, 695 p.

11. Marden, O. (1996). Volya y uspikh [Will and Success]: Per. from English. - Drohobych, $104 \mathrm{p}$.

УДК [159.1:82:930:37]:929(045)=111

DOI: 10.31339/2617-0833-2019-2(27)-137-141

COMPONENTS OF PSYCHOLOGY, LITERARY STUDIES, HISTORICAL AND PEDAGOGICAL SCIENCES AS THE FACTORS OF BIOGRAPHY STUDY

Rozman Iryna

\section{СКЛАДОВІ ПСИХОЛОГЇ̈, ЛІТРАТУРОЗНАВТВА, ІСТОРИКО-ПЕДАГОГІЧНИХ НАУК ЯК ЧИННИКИ ВИВЧЕННЯ БІОГРАФІЇ}

Розман I.I.

The article deals with the issues of studying the biographical approach through the lens of psychology, literary studies and historical and pedagogical sciences. It is stated that when studying the phenomenon of creativity it is necessary to take into account "the whole spectrum of individual manifestations of personality".

Key words: psychological analysis, historical disciplines, biographical studies, pedagogical biography.

У статті розглядаються питання вивчення біографічного підходу через призму психології, літературознавства та історико-педагогічних наук. Зазначено, щзо при вивченні феномену творчості необхідно враховувати «весь спектр індивідуальних проявів особистості». Закиентована увага на те, щчо розглядаючи біографію як психологічний феномен, саме вона документує особистість та ї історію $i$ демонструє пізнавальні можливості біографічного методу для соиіального проектування особистості. Доведено, щзо біографія має універсальний потенціал для вивчення иілісної особистості через історію ї формування $i$ розвитку. 3'ясовано, щуо тісний взаємозв'язок історико-педагогічної та історичної науки часто призводить до перетинання $і$ накладання предмету їхніх досліджень, хоча в теорії це розмежування визначено досить чітко. Висвітлено лінії перетинання між біографістикою в історико-педагогічній науцฺі та літературознавстві у спільних підходах до розв'язання концептуально значущьӧ проблеми співвідношення персоналї̈ (вчений, митець, письменник) та ї̈ творчості.

Ключові слова: психологічний аналіз, історичні дисципліни, біографічні дослідження, педагогічна біографістика.

Significant scientific-theoretical and research-instrumental potential has the experience of biographical approach developed in psychology. Scientists define in it three main components: biobiographical (study of objective living conditions, events of environment and behavior in it of the person); history of experiences (evolution of the human inner world); history of human creativity [4; 5 , p. 10-19; 6]. In this perspective, we note the productive idea for pedagogical biography that according to which in studying the phenomenon of creativity it is necessary to take into account "the 